ARTICLE

https://doi.org/10.1038/s41467-019-08473-x

\title{
Catalytic enantioselective oxidative coupling of saturated ethers with carboxylic acid derivatives
}

Gang Wang ${ }^{1}$, Xiaodong Xin², Zehua Wang ${ }^{2}$, Gang Lu², Yudao $\mathrm{Ma}^{2}$ \& Lei Liu (1) ${ }^{1,2}$

Catalytic enantioselective $\mathrm{C}-\mathrm{C}$ bond forming process through cross-dehydrogenative coupling represents a promising synthetic strategy, but it remains a long-standing challenge in chemistry. Here, we report a formal catalytic enantioselective cross-dehydrogenative coupling of saturated ethers with diverse carboxylic acid derivatives involving an initial oxidative acetal formation, followed by nickel(II)-catalyzed asymmetric alkylation. The one-pot, general, and modular method exhibits wide compatibility of a broad range of saturated ethers not only including prevalent tetrahydrofuran and tetrahydropyran, but also including mediumand large-sized cyclic moieties and acyclic ones with excellent enantioselectivity and functional group tolerance. The application in the rapid preparation of biologically active molecules that are difficult to access with existing methods is also demonstrated. 
T he cross-dehydrogenative coupling (CDC) of two readily available $\mathrm{C}-\mathrm{H}$ components has emerged as a powerful approach for $\mathrm{C}-\mathrm{C}$ bond construction whereby the only loss is $\mathrm{H}_{2}$ formally ${ }^{1-3}$. The design of the catalytic asymmetric variant is particularly attractive, but remains a challenging task ${ }^{4-6}$. Although impressive progress has been made in enantioselective CDC during the last decade, current studies predominantly focused on $N$-arylated amine ${ }^{7-19}$ and xanthese substrates ${ }^{20-25}$. In contrast, enantioselective CDC of ethers has remained scarce, and the unique existing two examples still focused on specific, activated benzylic and allylic ethers 26,27 . Our group described an enantioselective bimolecular CDC of cyclic benzylic ethers and aldehydes with high enantioselectivity ${ }^{26}$. Scheidt reported a delicate asymmetric intramolecular CDC of allylic ethers with appended $\beta$-keto esters, providing substituted tetrahydropyran-4ones with excellent diastereo- and enantioselectivities ${ }^{27}$. On the other hand, optically pure saturated ethers with diverse $a$-alkyl substitutions represent ubiquitous structural motifs in numerous bioactive natural products and synthetic pharmaceuticals ${ }^{28-30}$. However, each catalytic asymmetric method is typically suitable for a single class of tetrahydrofuran (THF), tetrahydropyran (THP), or acyclic ether skeleton with a specific a-alkyl substitution pattern ${ }^{31-46}$. A general and modular catalytic enantioselective method to rapidly access saturated ethers with diverse skeletons and $\alpha$-alkyl substituent patterns from readily available starting materials has remained elusive. Diverse saturated ether skeletons are basic feedstocks, and many of which, such as THF, THP, and diethyl ether, are daily used solvents in both academia and industry. Therefore, the development of catalytic asymmetric synthetic method starting from such abundant, low value chemical resources and $\mathrm{sp}^{3} \mathrm{C}-\mathrm{H}$ components is highly desirable. Herein, we report a formal catalytic enantioselective CDC of saturated ethers and carboxylic acid derivatives. The one-pot method exhibits wide compatibility of a broad range of saturated cyclic and acyclic ethers with excellent enantioselectivity. The application in the rapid preparation of biologically active molecules that are difficult to access with existing methods has also been demonstrated.

\section{Results}

Reaction design. Presumably, two major challenges hamper the design of catalytic asymmetric oxidative coupling starting from saturated ethers. First, due to the low reactivity of saturated ethers, the $\mathrm{C}-\mathrm{H}$ cleavage process requires strongly oxidative conditions, making the compatibility with delicate asymmetric catalysis system difficult to achieve ${ }^{47}$. Second, while catalytic asymmetric addition to aromatic oxocarbenium ions has received considerable attentions ${ }^{48-53}$, the lack of any site on non-aromatic oxocarbenium ions for substrate-catalyst interactions makes asymmetric synthesis of $\alpha$-substituted saturated ethers via such intermediates remains elusive ${ }^{54-56}$. Herein, we communicate a one-pot catalytic asymmetric synthetic method involving a broad range of saturated ethers and diverse carboxylic acid derivatives as starting materials. The one-pot synthetic method was designed as follow: saturated ether reacting with a combination of a protic additive and peroxide furnished a racemic acetal, which then ionized to corresponding oxocarbenium intermediate for enantioselective $\mathrm{C}-\mathrm{C}$ bond forging process.

Reaction condition optimization. The reaction of THF (1a) and acetyloxazolidinone 2a was selected for optimization using bisoxazoline $\mathrm{L} 1 / \mathrm{Mg}\left(\mathrm{ClO}_{4}\right)_{2}$ as chiral catalyst (Table 1) $)^{57-61}$. An initial survey revealed that oxidation of THF with hexanoic acid proceeded smoothly in the presence of ${ }^{\mathrm{t}} \mathrm{BuOOH}$ and a suitable additive, including TBAI, $\mathrm{Fe}(\mathrm{acac})_{3}, \mathrm{Cu}(\mathrm{acac})_{2}, \mathrm{Cu}(\mathrm{OAc})_{2}$, and
$\mathrm{CuOAc}^{62}$. However, these catalytic amount of additive exhibited a dramatic effect on the subsequent enantioselective $\mathrm{C}-\mathrm{C}$ bond forming reaction in the presence of $\mathrm{BF}_{3} \cdot \mathrm{OEt}_{2} / 2,4,6$-collidine, and $\mathrm{CuOAc}$ was identified to be optimal, providing expected $\mathbf{3 a}$ in $14 \%$ yield with $17 \%$ ee as a separable mixture of diastereomers (d. $\mathrm{r} .=50: 50)$ (entries 1-5, Table 1). Lowing the loading of CuOAc afforded an improved reaction efficiency and ee (entry 6, Table 1). Acetyloxazolidinethione $2 \mathrm{aa}$ proved to be a better component with regard to ee and yield (entry 7, Table 1). An extensive investigation of the combination of Lewis acid with chiral ligands L1-L6 revealed that diphosphine $\mathbf{L 6}$ and $\mathrm{Ni}(\mathrm{OTf})_{2}$ provided the highest yields and enantiocontrol (entries 8-17, Table 1). By using pre-prepared $\mathbf{L 6} \cdot \mathrm{Ni}(\mathrm{OTf})_{2}$ as catalyst, the yield increased from $55 \%$ to $61 \%$ without detriment to ee (entry 18, Table 1). By increasing the loading of $\mathrm{BF}_{3} \cdot \mathrm{OEt}_{2}$, the enantioselectivity and yield were improved to $90 \%$ and $86 \%$, respectively (entry 19 , Table 1). The reaction was also highly dependent on the solvent choice, and the nucleophilic addition stage worked the best in a mixed THF/ $\mathrm{CH}_{2} \mathrm{Cl}_{2}$ (entry 20, Table 1). The effect of protic additives was further explored, and reaction with $\mathrm{PhCOOH}$ furnished the product in $81 \%$ yield and $98 \%$ ee as a $67: 33$ mixture of diastereomers, which were separable through silica gel chromatography (entry 21, Table 1). The combination of $\mathrm{BF}_{3} \cdot \mathrm{OEt}_{2} /$ 2,4,6-collidine proved to be crucial to the expected reactivity (See Supplementary Table 1). No desired product was detected when $\mathrm{BF}_{3} \cdot \mathrm{OEt}_{2}$ was replaced with TMSOTf or 2,4,6-collidine with diisopropylethylamine. Lowering the reaction temperature for the asymmetric $\mathrm{C}-\mathrm{C}$ bond forming process did not provide any improvement on the diastereoselectivity (entry 22, Table 1).

Scope of acetic acid derivatives. The scope of acetic acid derivatives was then explored (Fig. 1). A variety of electron-donating and -withdrawing substituents at the ortho-, meta-, and parapositions of the aryl ring were well compatible with the reaction conditions, providing respective $a$-aryl acetamide substituted THF 3a-31 in good yields with moderate diastereoselectivity and excellent enantioselectivity (93-98\% ee) for both isomers. ( $\alpha$ Heteroaryl) 3o, as well as ( $\alpha$-nathphyl)acyl oxazolidinethiones $\mathbf{3 m}$ and $3 \mathbf{n}$ were suitable components in high enantioselectivities. $N$ phenylacyl thiazolidinethione was also well tolerated, as demonstrated by the generation of $3 p$ in $96 \%$ ee.

To further expand the synthetic utility of the method, we next investigated the possibility of $\alpha$-alkenyl acetic acid derivatives as coupling components (Fig. 2). Thiazolidinethione $\mathbf{3 r}$ was superior to oxazolidinethione $\mathbf{3 q}$ in terms of ee and yield. In general, the reaction exhibited excellent regioselectivity, and the alkylation occurred exclusively at the a-position of 3-butenoyl derivatives with olefin geometry highly conserved. Electronically varied $\gamma$ aryl substituted 3-butenoyl $2 \mathrm{~s}$ and $2 \mathrm{t}$ together with $\gamma$-alkyl substituted $2 \mathbf{u}-2 \mathbf{x}$ were competent components, providing corresponding 3s-3w in good yields with $90-96 \%$ ee. $\gamma$ Disubstituted $2 \mathrm{y}$ and $2 \mathrm{z}$ were also well tolerated in excellent enantiocontrol. The method had an excellent functional group tolerance, with common functionalities including terminal alkyne (3ba), benzoate (3bb), silyl ether (3bc), halide (3bd), and azide (3be) well tolerated in $90-92 \%$ ee for further manipulation. No expected product $3 \mathbf{b f}$ was observed when $\alpha$-alkyl acetic acid derivative $\mathbf{2 b f}$ was used as the coupling partner.

Scope of saturated ethers. The scope of saturated cyclic ethers was next examined (Fig. 3). Under the standard conditions, 1,1disubstituted THF proved to be competent substrates, furnishing trisubstituted THF $\mathbf{4 a}-\mathbf{4 c}$ in good yields with $94-96 \%$ ee and moderate d.r.. Enantioselective reaction of THP with $\alpha$-aryl and a-vinyl substituted acetic acid derivatives also proceeded 


\section{Table 1 Reaction condition optimization ${ }^{a}$}

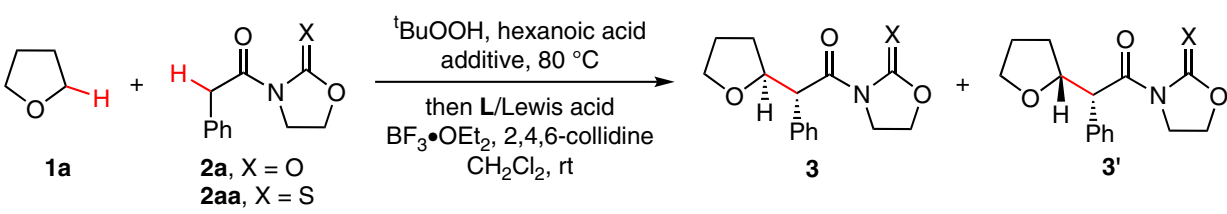<smiles>[R]C1COC(C(C)(C)C2=NC(P)CO2)=N1</smiles>

$\mathrm{L1}, \mathrm{R}=\mathrm{Ph}$ L2, $\mathrm{R}=i \mathrm{Pr}$<smiles>c1ccc(C2COC(c3cccc(C4=NC(c5ccccc5)CO4)n3)=N2)cc1</smiles>

L3<smiles>Pc1ccccc1-c1cccc2cccc(-c3ccccc3)c12</smiles><smiles>Pc1ccccc1-c1ccc2c(c1-c1ccccc1)OCO2</smiles><smiles>COc1ccccc1-c1c(OC)cccc1P(c1ccccc1)c1ccccc1</smiles>

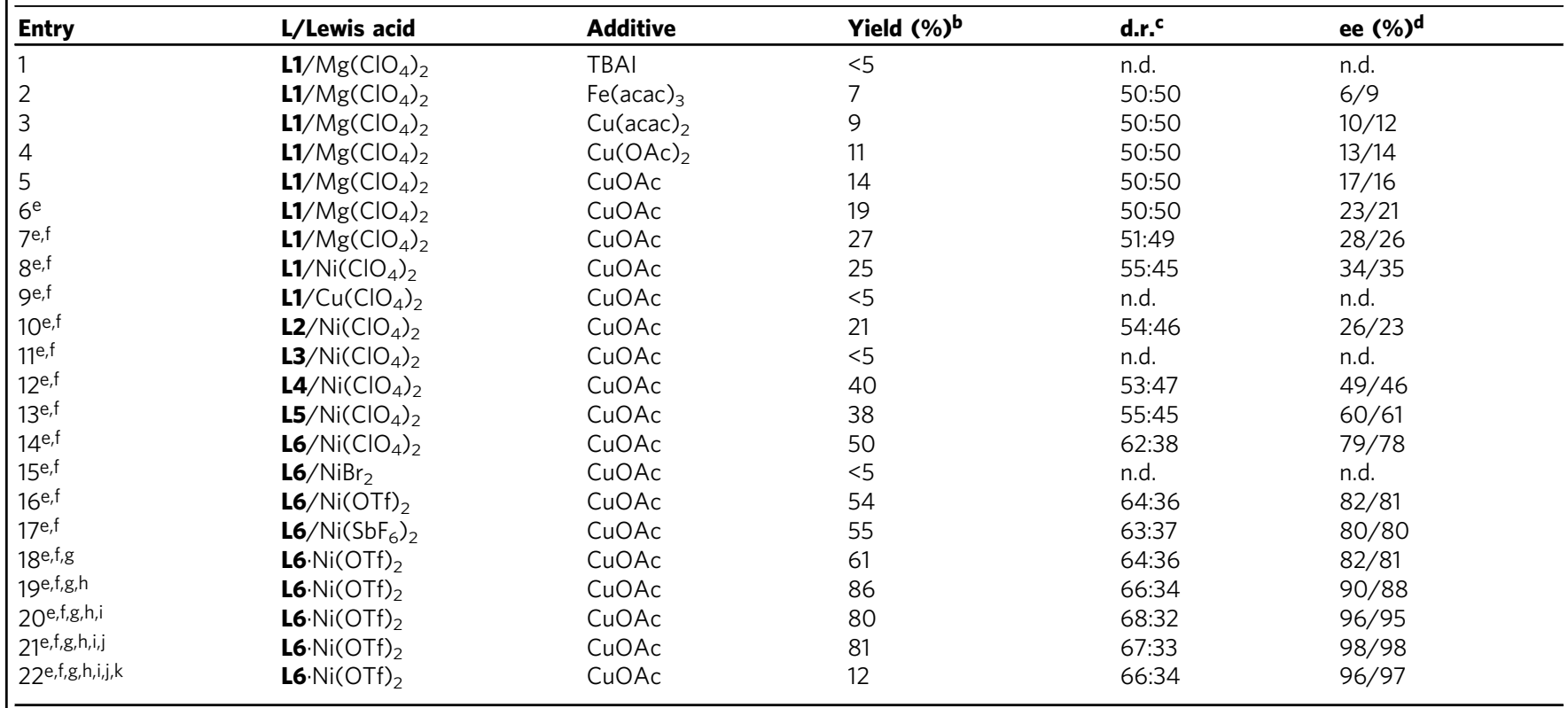

n.d., not determined

aReaction condition: hexanoic acid $\left(0.5 \mathrm{mmol}, 2.5\right.$ equiv), additive $(0.02 \mathrm{mmol}, 10 \mathrm{~mol} \%)$, and ${ }^{\mathrm{t} B u O O H}$ in decane $(0.5 \mathrm{mmol}, 2.5 \mathrm{equiv})$ in THF $(1 \mathrm{~mL})$ at $80{ }^{\circ} \mathrm{C}$ for $2 \mathrm{~h}$, followed by addition of $\mathbf{2 a}$ $\left(0.2 \mathrm{mmol}, 1.0\right.$ equiv), $\mathbf{L}(0.024 \mathrm{mmol}, 12 \mathrm{~mol} \%)$, Lewis acid $(0.02 \mathrm{mmol}, 10 \mathrm{~mol} \%), 2,4,6$-collidine $\left(0.6 \mathrm{mmol}, 3.0\right.$ equiv), and $\mathrm{BF}_{3} \cdot \mathrm{OEt}_{2}\left(0.6 \mathrm{mmol}, 3.0\right.$ equiv) in $\mathrm{CH}_{2} \mathrm{Cl} \mathrm{Cl}_{2}(0.4 \mathrm{~mL})$ at $\mathrm{rt}$ for $2 \mathrm{~h}$, unless otherwise noted

bIsolated yield of the two diastereomers

'Determined by ${ }^{1} \mathrm{H}$ NMR spectroscopy

dDetermined by chiral HPLC analysis

eCuOAc $(0.005 \mathrm{mmol}, 2.5 \mathrm{~mol} \%)$ used

${ }^{\dagger}$ Acetyloxazolidinethione 2 aa used

gPre-prepared $\mathbf{L 6} \cdot \mathrm{Ni}(\mathrm{OTf})_{2}$ used

$\mathrm{hBF}_{3} \cdot \mathrm{OEt}_{2}(0.8 \mathrm{mmol}, 4.0$ equiv) used

$\mathrm{THF} / \mathrm{CH}_{2} \mathrm{Cl}_{2}(3: 1, \mathrm{v} / \mathrm{v})$ as solvent for nucleophilic addition step

$\mathrm{PhCOOH}$ instead of hexanoic acid as protic additive

${ }^{k}$ Asymmetric nucleophilic addition reaction performed at $0^{\circ} \mathrm{C}$

smoothly, giving corresponding $\mathbf{4 d - 4 j}$ with excellent enantiocontrol. The success in the prevalent THF and THP frameworks encouraged us to further investigate the feasibility of enantioselective functionalization of larger cyclic ethers. Delightedly, medium-sized cyclic, aliphatic ethers, such as oxepane and oxocane, were tolerated, providing $\mathbf{4 k}$ and $\mathbf{4 1}$ in $96 \%$ ee and $92 \%$ ee, respectively. Albeit slightly decreased efficiency, large-sized cyclic, saturated ethers were also identified as competent substrates, as demonstrated by the generation of 13-membered $4 \mathrm{~m}$ and 16membered $\mathbf{4 n}$ in $96 \%$ ee and $95 \%$ ee. Although the scope of saturated cyclic ethers was not exclusively investigated, these results provide a proof-of-concept for the generality and modularity of the asymmetric synthetic method.

The tolerance of large-sized, cyclic ether prompted us to further explore the generality of the method for acyclic saturated ethers (Fig. 4). Pleasingly, enantioselective reaction of commonly used solvents, such as diethyl ether, dipropyl ether, and dibutyl ether, with 2aa proceeded smoothly, providing $\mathbf{6 a - 6 c}$ in good yields with $90-94 \%$ ee. Aside from symmetric acyclic ethers, unsymmetric ones also proved to be suitable substrates, as demonstrated by the highly enantioselective reaction of methyl nbutyl ether (6d) and methyl n-hexyl ether (6e). The reaction exhibited excellent regioselectivity, and no substitution at primary $\mathrm{C}-\mathrm{H}$ bond was observed. Acyclic ethers bearing a variety of commonly encountered functional groups, such as ether (6f), halide $(\mathbf{6 g})$, and acetate $(\mathbf{6 h})$, were also well tolerated for further manipulation. No improvement on the diastereoselectivity was observed when bulky tert-butyl ethyl ether (6i) was employed.

Synthetic applications. The synthetic utilities of the method was next explored (Fig. 5). First, the oxa- and thiazolidinethione 


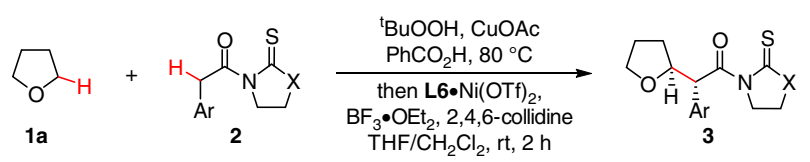

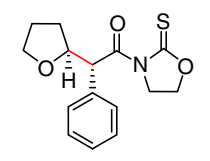

3aa, $81 \%$, d.r. $=2: 1$ $98 \%$ ee $/ 98 \%$ ee<smiles>O=C([C@@H](c1ccc(Cl)cc1)[C@@H]1CCCO1)N1CCOC1=S</smiles><smiles>COc1ccc(C(C(=O)N2CCOC2=S)[C@H]2CCCO2)cc1</smiles>

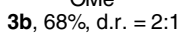
$96 \%$ ee $/ 97 \%$ ee
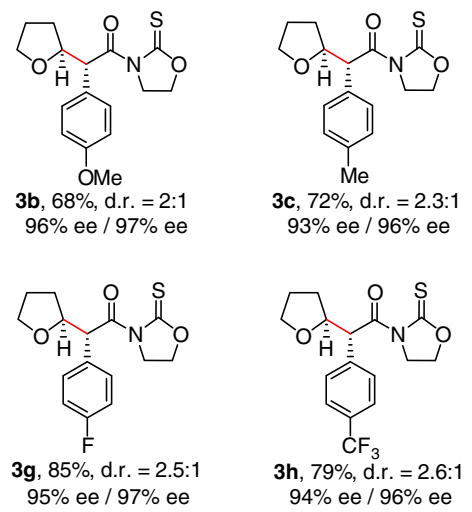

$3 c, 72 \%$, d.r. $=2.3: 1$
$93 \%$ ee $/ 96 \%$ ee
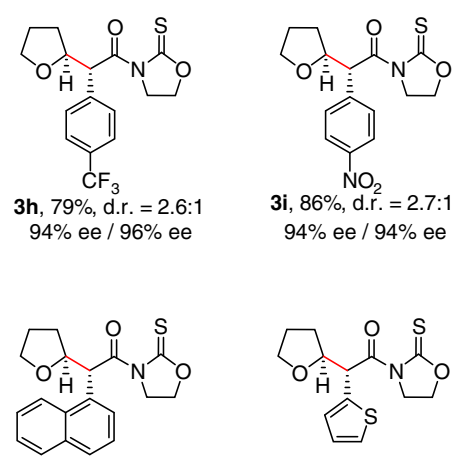
$97 \%$ ee $/ 98 \%$ ee
3I, $81 \%$, d.r. $=3: 1$<smiles>O=C([C@H](c1ccccc1Cl)C1CCCO1)N1CCOC1=S</smiles>

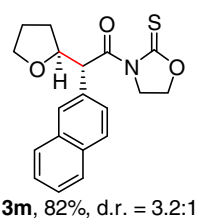

$3 \mathrm{~m}, 82 \%$, d.r. $=3.2: 1$
$96 \%$ ee $/ 97 \%$ ee
$3 n, 78 \%$, d.r. $=2.8: 1$ $96 \%$ ee $/ 97 \%$ ee

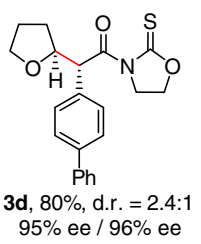

$94 \%$ ee / $94 \%$ ee
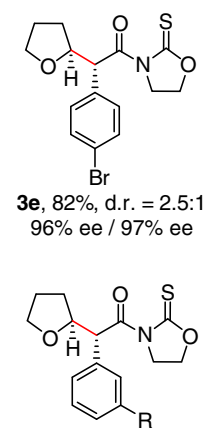
$\mathrm{R}=\mathrm{MeO}, \mathbf{3 j}, 65 \%$, d.r. $=2: 1$
$94 \%$ ee / $95 \%$ ee
$\mathrm{R}=\mathrm{Cl}, 3 \mathbf{3}, 83 \%$, d.r. $=2.7: 1$
$99 \%$ ee $/ 98 \%$ ee<smiles>O=C([C@H](c1cccs1)C1CCCO1)N1CCOC1=S</smiles>

$30,66 \%$, d.r. $=2.3: 1$ $93 \%$ ee $/ 92 \%$ ee

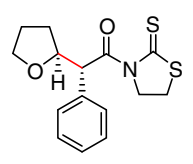

$3 p, 77 \%$, d.r. $=2: 1$

$96 \%$ ee $/ 96 \%$ ee

Fig. 1 The scope of $\alpha$-aryl acetic acid derivatives. Conditions: $\mathrm{PhCOOH}\left(0.5 \mathrm{mmol}, 2.5\right.$ equiv), $\mathrm{CuOAc}(2.5 \mathrm{~mol} \%),{ }^{\mathrm{t}} \mathrm{BuOOH}$ in decane (2.5 equiv) in THF $(1.0 \mathrm{~mL})$ at $80^{\circ} \mathrm{C}$ for $2 \mathrm{~h}$, followed by 2 (1.0 equiv), $\mathrm{L} 6 \cdot \mathrm{Ni}(\mathrm{OTf})_{2}(10 \mathrm{~mol} \%), 2,4,6$-collidine (3.0 equiv) and $\mathrm{BF}_{3} \cdot \mathrm{OEt}_{2}(4.0 \mathrm{equiv})$ in THF/CH $\mathrm{Cl}_{2}(0.3 \mathrm{~mL} /$ $0.1 \mathrm{~mL})$ at $\mathrm{rt}$ for $2 \mathrm{~h}$

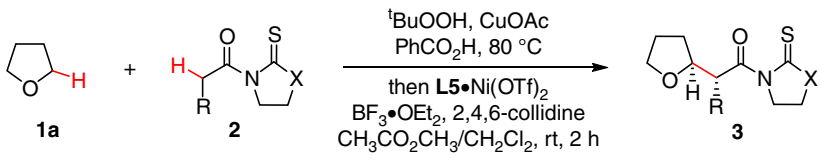

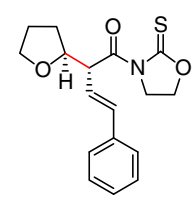

3q, $55 \%$, d.r. $=1.4: 1$ $93 \%$ ee / $89 \%$ ee<smiles>CC(C)/C=C/[C@H](C(=O)N1CCSC1=S)C1CCCO1</smiles>

$3 v, 66 \%$, d.r. $=2.1: 1$ $94 \%$ ee / $89 \%$ ee

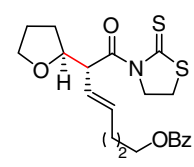

3bb, $65 \%$, d.r. $=2: 1$ $92 \%$ ee / $88 \%$ ee<smiles>O=C([C@H](/C=C/c1ccccc1)C1CCCO1)N1CCSC1=S</smiles>

3 r, $63 \%$, d.r. $=1.5: 1$ $95 \%$ ee / $90 \%$ ee<smiles>O=C([C@H](/C=C/c1ccccc1)C1CCCO1)N1CCSC1=S</smiles>

$3 w, 62 \%$, d.r. $=2.2: 1$ $91 \%$ ee $/ 87 \%$ ee<smiles>CCCCOc1ccc(/C=C/[C@H](C(=O)N2CCSC2=S)C2CCCO2)cc1</smiles>
$95 \%$ ee $/ 94 \%=2.1$<smiles>C/C=C\[C@H](C(=O)N1CCSC1=S)C1CCCO1</smiles>

$3 x, 72 \%$, d.r. $=2.1: 1$ $94 \%$ ee $/ 90 \%$ ee<smiles>[13CH3]/C=C/[C@@H](C(=O)N1CCSC1=S)C1CCCO1</smiles>

3bc, $61 \%$, d.r. $=2: 1$ $92 \%$ ee / $87 \%$ ee

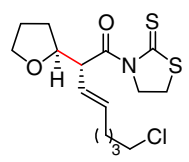

3bd, $66 \%$, d.r. $=2: 1$ $91 \%$ ee $/ 86 \%$ ee

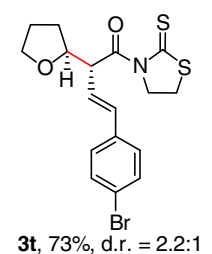

$96 \%$ ee $/ 91 \%$ ee

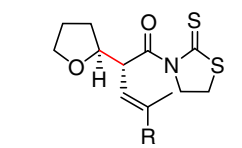

$\mathrm{R}=\mathrm{Ph}, \mathbf{3 y}, 64 \%$, d.r. $=2.5: 1$ $96 \%$ ee $/ 92 \%$ ee $\mathrm{R}=\mathrm{Me}, \mathbf{3 z}, \mathbf{7 5} \%$, d.r. $=2.3: 1$ $93 \%$ ee $/ 91 \%$ ee<smiles>NCCCCC(=O)C(=O)N1CCSC1=S</smiles>

be, $64 \%$, d.r. $=2: 1$ 3 be, $64 \%$, d.r. $=2:$
$90 \%$ ee $/ 86 \%$ ee<smiles>CCCC/C=C/[C@@H](C(=O)N1CCSC1=S)C1CCCO1</smiles>

$3 u, 67 \%$, d.r. $=1.7: 1$ $90 \%$ ee / $86 \%$ ee<smiles>C#CCNC=C[C@@H](C(=O)N1CCSC1=S)C1CCCO1</smiles>

3ba, $63 \%$, d.r. $=2: 1$ $90 \%$ ee / $87 \%$ ee<smiles>CCC(C(=O)N1CCSC1=S)C1CCCO1</smiles>

$3 \mathbf{b f},<5 \%$

Fig. 2 The scope of $\alpha$-alkenyl acetic acid derivatives. Conditions: $\mathrm{PhCOOH}\left(0.5 \mathrm{mmol}, 2.5\right.$ equiv), $\mathrm{CuOAc}(2.5 \mathrm{~mol} \%)$, ${ }^{\mathrm{B}} \mathrm{BuOOH}$ in decane (2.5 equiv) in THF $(1.0 \mathrm{~mL})$ at $80^{\circ} \mathrm{C}$ for $2 \mathrm{~h}$, followed by 2 (1.0 equiv), L5. Ni(OTf) 2 (10 mol\%), 2,4,6-collidine (3.0 equiv), and $\mathrm{BF}_{3} \cdot \mathrm{OEt}_{2}\left(4.0\right.$ equiv) in $\mathrm{CH}_{3} \mathrm{CO}_{2} \mathrm{CH}_{3} / \mathrm{CH}_{2} \mathrm{Cl}_{2}$ $(0.3 \mathrm{~mL} / 0.1 \mathrm{~mL})$ at $\mathrm{rt}$ for $2 \mathrm{~h}$ 


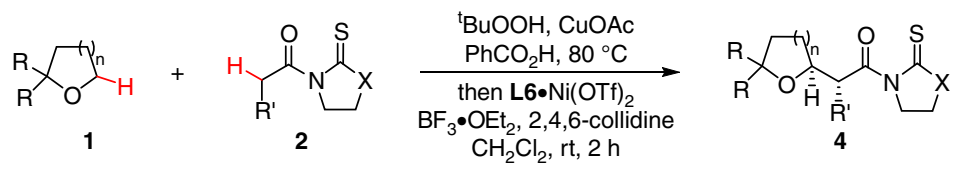

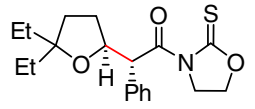

$4 a, 76 \%$, d.r. $=3.5: 1$ $95 \%$ ee / $95 \%$ ee<smiles>O=C([C@H](c1ccc(Cl)cc1)C1CCCCO1)N1CCOC1=S</smiles>

$$
\text { 4f, } 65 \% \text {, d.r. }=2.3: 1
$$
$97 \%$ ee / $97 \%$ ee<smiles>O=C([C@H](c1ccccc1)C1CCCCO1)N1CCSC1=S</smiles>

4k, $58 \%$, d.r. $=1.5: 1$ $96 \%$ ee / $94 \%$ ee

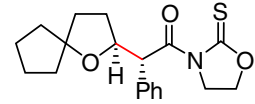

4b, $77 \%$, d.r. $=3.8: 1$ $94 \%$ ee / $95 \%$ ee<smiles>O=C([C@H](c1ccc(C(F)(F)F)cc1)C1CCCCO1)N1CCSC1=S</smiles>

$4 \mathrm{~g}, 63 \%$, d.r. $=2.5: 1$ $94 \%$ ee / $94 \%$ ee

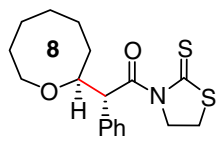

4I, $46 \%$, d.r. = 1.3: 1 $92 \%$ ee / $93 \%$ ee<smiles>O=C(C1CCC2(CCCCC2)O1)C([PH+])N1CCOC1=S</smiles>

$4 c, 72 \%$, d.r. $=4: 1$ $95 \%$ ee $/ 96 \%$ ee<smiles></smiles>

$4 h, 51 \%$, d.r. $=1.5: 1$ $92 \%$ ee / $89 \%$ ee

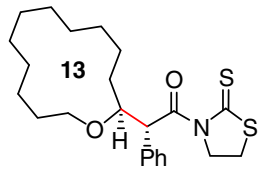

$4 \mathrm{~m}, 33 \%$, d. $\mathrm{r}=13.1$ $96 \%$ ee $/ 94 \%$ ee

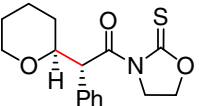

4d, $60 \%$, d.r. $=1.9: 1$ $96 \%$ ee / $96 \%$ ee$$
\text { (96\% } / 96 \% \text { ee }
$$

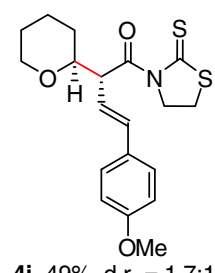

$4 \mathbf{i}, 49 \%$, d.r. $=1.7: 1$ $95 \%$ ee / $91 \%$ ee

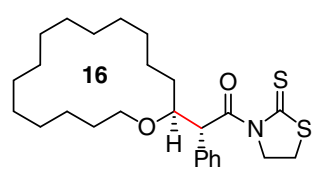

$4 n, 29 \%$, d.r. $=1.1: 1$

$95 \%$ ee / $94 \%$ ee

Fig. 3 The scope of cyclic saturated ethers. Conditions: $\mathrm{PhCOOH}\left(0.5 \mathrm{mmol}, 2.5\right.$ equiv), $\mathrm{CuOAc}(2.5 \mathrm{~mol} \%)$, ${ }^{\mathrm{B} u O O H}$ in decane (3.0 equiv) in ether $\left(1.0 \mathrm{~mL}\right.$ ) at $80^{\circ} \mathrm{C}$ for $6-12 \mathrm{~h}$, followed by 2 (1.0 equiv), L5. Ni(OTf) ${ }_{2}$ or $\mathrm{L} 6 \cdot \mathrm{Ni}(\mathrm{OTf})_{2}(10 \mathrm{~mol} \%), 2,4,6$-collidine (3.0 equiv), and $\mathrm{BF}_{3} \cdot \mathrm{OEt}_{2}(4.0$ equiv) in $\mathrm{CH}_{2} \mathrm{Cl}_{2}(0.4 \mathrm{~mL})$ at $\mathrm{rt}$ for $2 \mathrm{~h}$

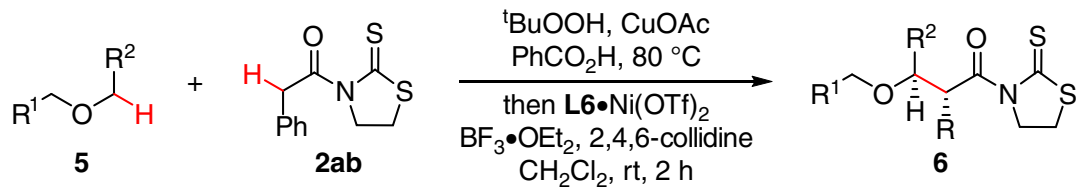<smiles>CCOC(C)[C@@H](C(=O)N1CCSC1=S)c1ccccc1</smiles>

6a, $65 \%$, d.r. $=1: 1$ $90 \%$ ee / $88 \%$ ee<smiles>COC(C)C(=O)N1CCSC1=S</smiles>

6 d, $45 \%$, d.r. $=1: 1$ $95 \%$ ee $/ 94 \%$ ee

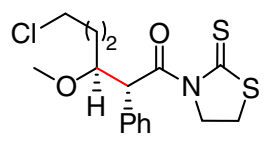

$6 \mathbf{g}, 37 \%$, d.r. $=1: 1$ $93 \%$ ee / $95 \%$ ee<smiles>CCCOC(C)(C)[C@H](C(=O)N1CCSC1=S)c1ccccc1</smiles>

6b, $62 \%$, d.r. $=1: 1$ $92 \%$ ee / $93 \%$ ee<smiles>COC(C)C(=O)[C@@H](C(=O)N1CCSC1=S)c1ccccc1</smiles>

$6 e, 50 \%$, d.r. $=1: 1$ $93 \%$ ee / $93 \%$ ee<smiles>CO[C@H](NCOC(C)=O)C(C(=O)N1CCSC1=S)c1ccccc1</smiles>

6h, $34 \%$, d.r. = 1:1 $95 \%$ ee / $95 \%$ ee<smiles>CCCCCCC(C)(OCC=Cc1ccccc1)C(C(=O)N1CCSC1=S)c1ccccc1</smiles>

$6 \mathrm{c}, 57 \%$, d.r. $=1: 1$ $94 \%$ ee / $95 \%$ ee<smiles>COCCC(OC)[C@H](C(=O)N1CCSC1=S)c1ccccc1</smiles>

6f, $40 \%$, d.r. $=1: 1$ $94 \%$ ee / $94 \%$ ee<smiles>CCOC(C(=O)N1CCSC1=S)[C@H](c1ccccc1)C(C)(C)C</smiles>

$6 i$, $8 \%$, d.r. $=1: 1$ $94 \%$ ee / $95 \%$ ee

Fig. 4 The scope of acyclic saturated ethers. Conditions: $\mathrm{PhCOOH}\left(0.5 \mathrm{mmol}, 2.5\right.$ equiv), $\mathrm{CuOAc}(2.5 \mathrm{~mol} \%)$, ${ }^{\mathrm{BuOOH}}$ in decane (3.0 equiv) in ether

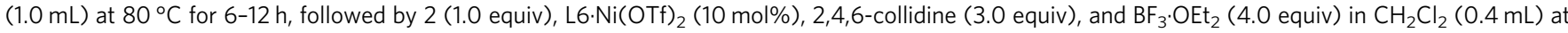
rt for $2 \mathrm{~h}$ 
a

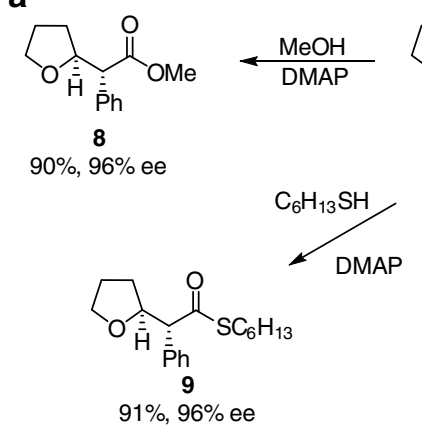

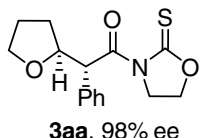
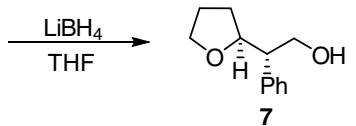

3aa, 98\% e
7 $85 \%, 97 \%$ ee

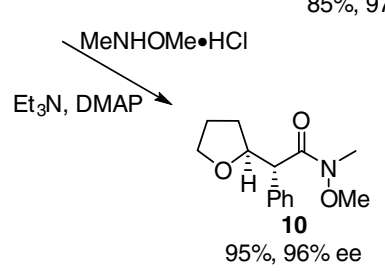

c

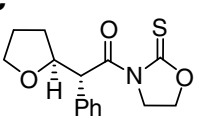

3aa, 98\% ee

1) DIBAL-H

2) $\mathrm{Ru}\left(\mathrm{PPh}_{3}\right)_{3} \mathrm{Cl}$

benzene, $70{ }^{\circ} \mathrm{C}$

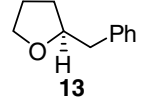

$62 \%, 95 \%$ ee

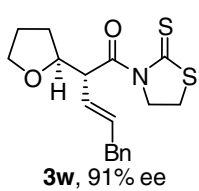

1) DIBAL-H

$\mathrm{CH}_{2} \mathrm{Cl}_{2},-78^{\circ} \mathrm{C}$

2) $\mathrm{Ru}\left(\mathrm{PPh}_{3}\right)_{3} \mathrm{Cl}$

benzene, $70^{\circ} \mathrm{C}$

3) $\mathrm{Pd} / \mathrm{C}, \mathrm{H}_{2}, \mathrm{MeOH}$

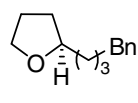

14

$58 \%, 87 \%$ ee

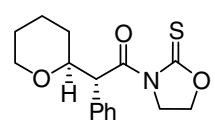

1) DIBAL-H

4d, $96 \%$ ee

1) standard asymmetric coupling condition 2) $\mathrm{MeOH}, \mathrm{DMAP}$
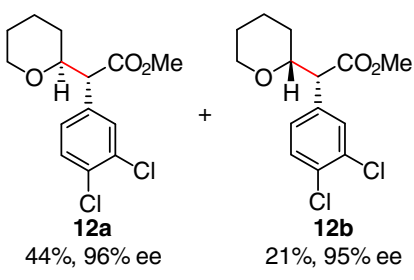

Dopamine transporter inhibitors<smiles>O=C([C@H](/C=C/Br)C1CCCCO1)N1CCSC1=S</smiles>

4j, $90 \%$ ee<smiles>COC(C)(S)[C@@H](C(=O)N1CCSC1=S)c1ccccc1</smiles>

6e, $93 \%$ ee

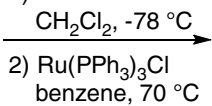

1) DIBAL-H $\underset{\mathrm{CH}_{2} \mathrm{Cl}_{2},-78^{\circ} \mathrm{C}}{\mathrm{Ru}\left(\mathrm{PPh}_{3}\right)_{3} \mathrm{Cl}}$ benzene, $70^{\circ} \mathrm{C}$ 3) $\mathrm{Pd} / \mathrm{C}, \mathrm{H}_{2}, \mathrm{MeOH}$<smiles>c1ccc(CC2CCCCO2)cc1</smiles>
$60 \%, 96 \%$ ee<smiles>CC(CBr)C1CCCCO1</smiles>

\section{1) DIBAL-H 2) $\mathrm{Ru}\left(\mathrm{PPh}_{3}\right)_{3} \mathrm{Cl}$ benzene, $70^{\circ} \mathrm{C}$}

Fig. 5 Synthetic utilities. a Transformations of oxa- and thiazolidinethiones to other synthetically valuable functional groups. b Rapid synthesis of two dopamine transporter inhibitors. c Removal of the oxa- and thiazolidinethione moieties

a<smiles>O=C(O)C(=O)OC1CCCO1</smiles>

b<smiles>CC(=O)OC(=O)N1CCOC1=S</smiles>

C $18+$ 2aa $\quad \underset{\mathrm{BF}_{3} \cdot \mathrm{OEt}_{2}, 2,4,6 \text {-collidine }}{\mathrm{THF} / \mathrm{CH}_{2} \mathrm{Cl}_{2}, \mathrm{rt}}$

d $18+$ 2aa $\stackrel{\mathrm{BF}_{3} \cdot \mathrm{OEt}_{2}, 2,4,6 \text {-collidine }}{\mathrm{THF} / \mathrm{CH}_{2} \mathrm{Cl}_{2}, \mathrm{rt}} \quad \begin{gathered}\text { 3aa } \\ <5 \%\end{gathered}$

Fig. 6 Mechanistic studies. a Reaction intermediate identification. b Asymmetric coupling of 18 with 2aa. c Asymmetric coupling of 18 with 2aa in the absence of CuOAc. d Identification of the real metal catalyst for the asymmetric coupling

moieties can be readily converted to other synthetically valuable functional groups. For example, the adduct 3a was converted to corresponding alcohol $\mathbf{7}$, ester $\mathbf{8}$, thioester $\mathbf{9}$, and Weinreb amide 10 in high efficiency with the ee highly conserved (Fig. 5a). Enantiopure diastereomers $\mathbf{1 2} \mathbf{a}$ and $\mathbf{1 2} \mathbf{b}$ are potent and selective dopamine transporter inhibitors (Fig. 5b) ${ }^{63}$. However, traditional synthetic method, which relied on menthol or 1-indanol mediated resolution technology, required seven steps for each isomer preparation starting from 3,4-dihydro-2H-pyran. Our method exhibited moderate diastereoselectivity, which afforded an opportunity to rapidly access both $\mathbf{1 2 a}$ and $\mathbf{1 2 b}$ in excellent ee through a two-step process consisting of asymmetric reaction of THP (1d) with 11 and esterification. Second, given the tolerance of a broad range of carboxylic acid derivatives, we envisioned that removing the exocyclic stereocenter would further enhance the synthetic utility of the protocol. Therefore, we designed a concise two-step sequence involving DIBAL-H mediated reduction of oxa- or thiazolidinethione to aldehyde followed by $\mathrm{Ru}\left(\mathrm{PPh}_{3}\right)_{3} \mathrm{Cl}$ catalyzed decarbonylation, providing $\alpha$-alkyl substituted saturated ethers 13-17 that are difficult to prepare by other methods (Fig. 5c).

\section{Discussion}

Control experiments were conducted to gain a preliminary understanding of the reaction mechanism (Fig. 6). First, in the presence of $\mathrm{CuOAc}$ and ${ }^{\mathrm{t}} \mathrm{BuOOH}$, THF (1a) reacted with $\mathrm{PhCO}_{2} \mathrm{H}$ giving acetate 18 in $88 \%$ yield (Fig. 6a). Subjecting 18 to the standard condition furnished expected 3 aa with comparable results to that observed in the reaction starting from THF (1a) (Fig. 6b). The observations implied the intermediacy of 18 in the process. Second, the alkylation of $\mathbf{1 8}$ with 2 aa proceeded smoothly under the standard reaction condition in the absence of oxidation elements (Fig. 6c). No expected 3aa was observed when the combination of $\mathbf{L 6}$ and CuOAc was used as the catalyst (Fig. 6d). These results suggested that the species binding to diphosphine ligand should be $\mathrm{Ni}(\mathrm{OTf})_{2}$ but not $\mathrm{CuOAc}$.

Based on the above observations, a plausible catalytic cycle is outlined in Fig. 7. Carboxylic acid derivative 2aa coordinates with L6. $\mathrm{Ni}(\mathrm{OTf})_{2}$ complex giving rise to 19 , in which the acidity of the hydrogen $a$ to the carbonyl moiety increases. 2,4,6-Collidine 


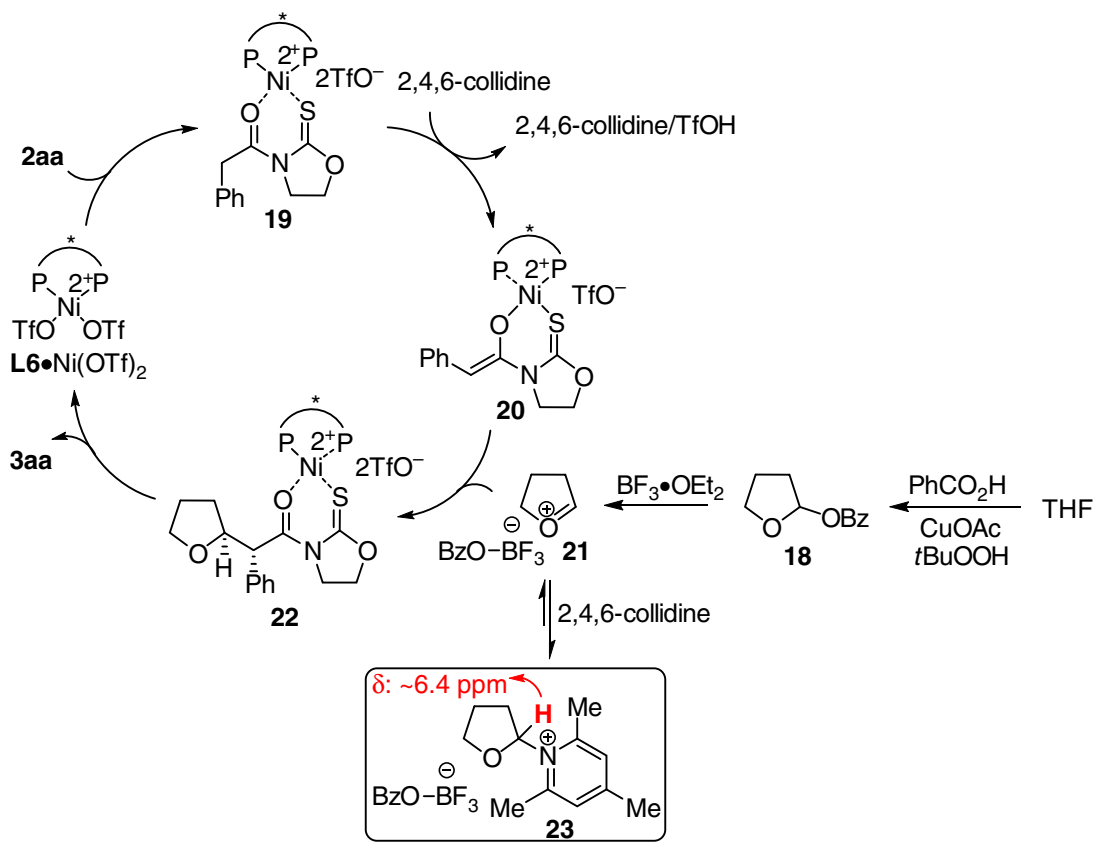

Fig. 7 A proposed catalytic cycle. The possible reaction pathway based on our studies and previous literature

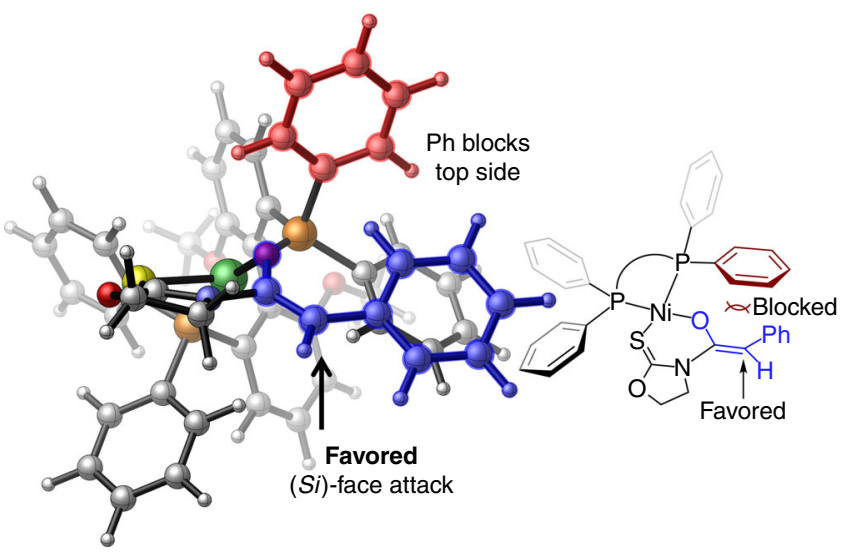

Fig. 8 Stereochemical induction model with chiral Ni-bound Z-enolate. The geometry was optimized at the B3LYP/LANL2DZ-6-31G(d) level

promotes the enolization of 19 providing chiral Ni-bound $Z$ enolate $20^{64}$. 20 Reacts with cyclic oxocarbenium 21 generated in situ from acetal 18 and $\mathrm{BF}_{3} \cdot \mathrm{OEt}_{2}$ yielding 22. Product dissociation completes the catalytic cycle. Notably, no reactivity was detected when diisopropylethylamine was used instead of 2,4,6collidine, indicating that the role of latter might not simply act as a base. Fujioka and Kita reported that in the presence of a suitable Lewis acid, the acetal reacted with 2,4,6-collidine furnishing corresponding pyridinium-type salt ${ }^{65}$. During our in situ ${ }^{1} \mathrm{H}$ $\mathrm{NMR}$ study of the mixture of acetal 18, $\mathrm{BF}_{3} \cdot \mathrm{OEt}_{2}$, and 2,4,6collidine, a peak at $\delta \sim 6.4 \mathrm{ppm}$ was observed, which is characteristic for such type of pyridinium species ${ }^{65,66}$. Accordingly, we envisioned that 2,4,6-collidine might react with oxocarbenium 21 reversibly furnishing pyridinium 23. Adduct 23 possessing weak electrophilicity might be considered as a reservoir of $\mathbf{2 1}$ to prevent the decomposition before the capture by enolate 20 .

The stereochemical induction model based on the Ni-bound $Z$ enolate with chiral bidentate phosphine ligand L6 (MeOBIPHEP) was proposed in Fig. 8. The $P$-bound phenyl group on the ligand (in red) shields the top face ( $R e$ face) of the enolate substrate (in blue), which disfavors the electrophilic attack by the oxocarbenium intermediate. In contrast, the addition of the oxocarbenium ion to the Si face of the enolate substrate is favored due to less repulsive interactions with the ligand. This model is consistent with the experimentally observed stereochemistry. The low to moderate diastereoselectivity observed for saturated ethers might be ascribed to the lack of Lewis basic site on corresponding oxocarbenium ion intermediates for substrate-catalyst interactions.

In summary, a one-pot catalytic enantioselective reaction of saturated ethers with diverse carboxylic acid derivatives is described. The general and modular method exhibits wide compatibility of a broad range of saturated cyclic ethers not only including prevalent THF and THP, but also including mediumand large-sized cyclic moieties with excellent enantioselectivity and functional group tolerance. The generality of the method is further demonstrated by application in saturated acyclic ethers. The synthetic application in the rapid preparation of biologically active molecules that are difficult to access with existing methods is demonstrated. We envision that the general, modular, and highly enantioselective reaction of abundant, low value saturated ethers outlined herein will provide a topologically straightforward synthetic planning for both complex target molecules and a plethora of analogs for lead discovery and optimization.

\section{Methods}

General procedure for the reaction of THF (1a) with 2aa. In an oven-dried Teflon septum screw-capped tube, $\mathrm{PhCOOH}(61 \mathrm{mg}, 0.5 \mathrm{mmol}), \mathrm{CuOAc}(0.6 \mathrm{mg}$, $0.005 \mathrm{mmol}, 2.5 \mathrm{~mol} \%)$, and ${ }^{\mathrm{BuOOH}}$ in decane $(0.5 \mathrm{mmol})$ were added to THF $(1.0 \mathrm{~mL})$. The solution was stirred at $80^{\circ} \mathrm{C}$ for $2 \mathrm{~h}$ before the solvent was evaporated. Then carboxylic acid derivative $\mathbf{2 a a}(44.3 \mathrm{mg}, 0.2 \mathrm{mmol}), \mathbf{L 6} \cdot \mathrm{Ni}(\mathrm{OTf})_{2}$ (18.7 mg, $0.02 \mathrm{mmol}), 2,4,6$-collidine $(79.3 \mu \mathrm{L}, 0.6 \mathrm{mmol})$, and $\mathrm{BF}_{3} \cdot \mathrm{OEt}_{2}(98.7 \mu \mathrm{L}$, $0.8 \mathrm{mmol})$ in $\mathrm{THF} / \mathrm{CH}_{2} \mathrm{Cl}_{2}(0.3 \mathrm{~mL} / 0.1 \mathrm{~mL}, \mathrm{v}-\mathrm{v})$ was added. After stirring at $\mathrm{rt}$ for $2 \mathrm{~h}$, solvents were removed and the residue was purified by silica gel column chromatography $\left(\mathrm{CH}_{2} \mathrm{Cl}_{2} /\right.$ ethyl acetate $\left.=99: 1\right)$ giving the expected 3aa in $81 \%$ yield $(47.2 \mathrm{mg}$ ) with $98 \%$ ee as a separable mixture of diastereomers (d.r. $=2: 1)$.

\section{Data availability}

The authors declare that the data supporting the findings of this study are available within the article and its Supplementary Information files. The X-ray crystallographic coordinates for structures reported in this article have been deposited at the Cambridge Crystallographic Data Center (3p: CCDC 1858037, 3p': 
CCDC 1858065, 3s: CCDC 1858049, 4e: CCDC 1858043, 4l: CCDC 1890776). These data could be obtained free of charge from The Cambridge Crystallographic Data Center via www.ccdc.cam.ac.uk/data_request/cif.

Received: 22 October 2018 Accepted: 15 January 2019

Published online: 04 February 2019

\section{References}

1. Li, C.-J. Cross-dehydrogenative coupling (CDC): exploring $\mathrm{C}-\mathrm{C}$ bond formations beyond functional group transformations. Acc. Chem. Res. 42 , 335-344 (2009).

2. Girard, S. A., Knauber, T. \& Li, C.-J. The cross-dehydrogenative coupling of $\mathrm{C}_{\mathrm{sp} 3}-\mathrm{H}$ bonds: a versatile strategy for $\mathrm{C}-\mathrm{C}$ bond formations. Angew. Chem. Int. Ed. 53, 74-100 (2014).

3. Liu, C., Zhang, H., Shi, W. \& Lei, A. Bond formations between two nucleophiles: transition metal catalyzed oxidative cross-coupling reactions. Chem. Rev. 111, 1780-1824 (2011).

4. Zheng, C. \& You, S.-L. Recent development of direct asymmetric functionalization of inert C-H bonds. RSC Adv. 4, 6173-6214 (2014).

5. Qin, Y., Lv, J. \& Luo, S. Catalytic asymmetric a-C $\left(\mathrm{sp}^{3}\right)-\mathrm{H}$ functionalization of amines. Tetrahedron Lett. 55, 551-558 (2014).

6. Yang, L. \& Huang, H. Asymmetric catalytic carbon-carbon coupling reactions via C-H bond activation. Catal. Sci. Technol. 2, 1099-1122 (2012).

7. $\mathrm{Li}, \mathrm{Z}$. \& Li, C.-J. Catalytic enantioselective alkynylation of prochiral $\mathrm{sp}^{3} \mathrm{C}-\mathrm{H}$ bonds adjacent to a nitrogen atom. Org. Lett. 6, 4997-4999 (2004).

8. Tan, Y., Yuan, W., Gong, L. \& Meggers, E. Aerobic asymmetric dehydrogenative cross-coupling between two $\mathrm{C}-\mathrm{H}$ groups catalyzed by a chiral-at-metal rhodium complex. Angew. Chem. Int. Ed. 54, 13045-13048 (2015).

9. Zhang, J., Tiwari, B., Xing, C., Chen, X. \& Chi, Y. R. Enantioselective oxidative cross-dehydrogenative coupling of tertiary amines to aldehydes. Angew. Chem. Int. Ed. 51, 3649-3652 (2012).

10. Zhang, G., Zhang, Y. \& Wang, R. Catalytic asymmetric activation of $\mathrm{a} \mathrm{C}_{\mathrm{sp} 3}-\mathrm{H}$ bond adjacent to a nitrogen atom: a versatile approach to optically active $\alpha$ alkyl $\alpha$-amino acids and $\mathrm{C} 1$-alkylated tetrahydroisoquinoline derivatives. Angew. Chem. Int. Ed. 50, 10429-10432 (2011).

11. Zhang, G., Ma, Y., Wang, S., Zhang, Y. \& Wang, R. Enantioselective metal/ organo-catalyzed aerobic oxidative $\mathrm{sp}^{3} \mathrm{C}-\mathrm{H}$ olefination of tertiary amines using molecular oxygen as the sole oxidant. J. Am. Chem. Soc. 134, 12334-12337 (2012)

12. DiRocco, D. A. \& Rovis, T. Catalytic asymmetric $\alpha$-acylation of tertiary amines mediated by a dual catalysis mode: $N$-heterocyclic carbene and photoredox catalysis. J. Am. Chem. Soc. 134, 8094-8097 (2012).

13. Neel, A. J., Hehn, J. P., Tripet, P. F. \& Toste, F. D. Asymmetric crossdehydrogenative coupling enabled by the design and application of chiral triazole-containing phosphoric acids. J. Am. Chem. Soc. 135, 14044-14047 (2013).

14. Liu, X., Meng, Z., Li, C., Lou, H. \& Liu, L. Organocatalytic enantioselective oxidative $\mathrm{C}-\mathrm{H}$ alkenylation and arylation of $\mathrm{N}$-carbamoyl tetrahydropyridines and tetrahydro- $\beta$-carbolines. Angew. Chem. Int. Ed. 54, 6012-6015 (2015).

15. Wei, G. et al. Enantioselective aerobic oxidative $\mathrm{C}\left(\mathrm{sp}^{3}\right)-\mathrm{H}$ olefination of amines via cooperative photoredox and asymmetric catalysis. ACS Catal. 6 , 3708-3712 (2016).

16. Shang, $\mathrm{M}$. et al. $\mathrm{C}-\mathrm{H}$ functionalization of amines via alkene-derived nucleophiles through cooperative action of chiral and achiral Lewis acid catalysts: applications in enantioselective synthesis. J. Am. Chem. Soc. 140, 10593-10601 (2018).

17. Yang, Q. et al. Visible-light-promoted asymmetric cross-dehydrogenative coupling of tertiary amines to ketones by synergistic multiple catalysis. Angew. Chem. Int. Ed. 56, 3694-3698 (2017)

18. Zhou, G., Liu, F. \& Zhang, J. Enantioselective gold-catalyzed functionalization of unreactive $\mathrm{sp}^{3} \mathrm{C}-\mathrm{H}$ bonds through a redox-neutral domino reaction. Chem. Eur. J. 17, 3101-3104 (2011).

19. Milo, A., Neel, A. J., Toste, F. D. \& Sigman, M. S. A data-intensive approach to mechanistic elucidation applied to chiral anion catalysis. Science 347, 737-743 (2015).

20. Benfatti, F., Guiteras Capdevila, M., Zoli, L., Benedetto, E. \& Cozzi, P. G. Catalytic stereoselective benzylic $\mathrm{C}-\mathrm{H}$ functionalizations by oxidative $\mathrm{C}-\mathrm{H}$ activation and organocatalysis. Chem. Commun. 45, 5919-5921 (2009).

21. Guo, C., Song, J., Luo, S. W. \& Gong, L. Z. Enantioselective oxidative crosscoupling reaction of 3-indolylmethyl $\mathrm{C}-\mathrm{H}$ Bonds with 1,3-dicarbonyls using a chiral lewis acid-bonded nucleophile to control stereochemistry. Angew. Chem. Int. Ed. 49, 5558-5562 (2010).

22. Cao, W. et al. Catalytic asymmetric cross-dehydrogenative coupling: activation of $\mathrm{C}-\mathrm{H}$ bonds by a cooperative bimetallic catalyst system. Chem. Commun. 49, 3470-3472 (2013).
23. Deng, T., Wang, H. \& Cai, C. Copper-catalyzed asymmetric oxidative crosscoupling of 2-naphthols with aryl methyl ketones. Eur. J. Org. Chem. 2015, 1569-1574 (2015)

24. Narute, S. \& Pappo, D. Iron phosphate catalyzed asymmetric crossdehydrogenative coupling of 2-naphthols with $\beta$-ketoesters. Org. Lett. 19, 2917-2920 (2017).

25. Zhang, B., Xiang, S.-K., Zhang, L.-H., Cui, Y. \& Jiao, N. Organocatalytic asymmetric intermolecular dehydrogenative a-alkylation of aldehydes using molecular oxygen as oxidant. Org. Lett. 13, 5212-5215 (2011).

26. Meng, Z., Sun, S., Yuan, H., Lou, H. \& Liu, L. Catalytic enantioselective oxidative cross-coupling of benzylic ethers with aldehydes. Angew. Chem. Int. Ed. 53, 543-547 (2014).

27. Lee, A., Betori, R. C., Crane, E. A. \& Scheidt, K. A. An enantioselective crossdehydrogenative coupling catalysis approach to substituted tetrahydropyrans. J. Am. Chem. Soc. 140, 6212-6216 (2018).

28. Faul, M. M. \& Huff, B. E. Strategy and methodology development for the total synthesis of polyether ionophore antibiotics. Chem. Rev. 100, 2407-2474 (2000).

29. Kang, E. J. \& Lee, E. Total synthesis of oxacyclic macrodiolide natural products. Chem. Rev. 105, 4348-4378 (2005).

30. Wolfe, J. P. \& Hay, M. B. Recent advances in the stereoselective synthesis of tetrahydrofurans. Tetrahedron 63, 261-290 (2007).

31. Zhang, Z., Butt, N. A. \& Zhang, W. Asymmetric hydrogenation of nonaromatic cyclic substrates. Chem. Rev. 116, 14769-14827 (2016).

32. Song, S., Zhu, S.-F., Pu, L.-Y. \& Zhou, Q.-L. Iridium-catalyzed enantioselective hydrogenation of unsaturated heterocyclic acids. Angew. Chem. Int. Ed. 52, 6072-6075 (2013).

33. Kang, S. H., Lee, S. B. \& Park, C. M. Catalytic enantioselective iodocyclization of $\gamma$-hydroxy-cis-alkenes. J. Am. Chem. Soc. 125, 15748-15749 (2003).

34. Zhou, P. et al. Catalytic asymmetric intra-and intermolecular haloetherification of enones: an efficient approach to (-)-Centrolobine. ACS Catal. 6, 7778-7783 (2016).

35. Bovino, M. T. et al. Enantioselective copper-catalyzed carboetherification of unactivated alkenes. Angew. Chem. Int. Ed. 53, 6383-6387 (2014).

36. Chung, Y. K. \& Fu, G. C. Phosphine-catalyzed enantioselective synthesis of oxygen heterocycles. Angew. Chem. Int. Ed. 48, 2225-2227 (2009).

37. Blanc, A. \& Toste, F. D. Enantioselective synthesis of cyclic ethers through a vanadium-catalyzed resolution/oxidative cyclization. Angew. Chem. Int. Ed. 45, 2096-2099 (2006).

38. Tanaka, S., Seki, T. \& Kitamura, M. Asymmetric dehydrative cyclization of $\omega$ hydroxy allyl alcohols catalyzed by ruthenium complexes. Angew. Chem. Int. Ed. 48, 8948-8951 (2009).

39. Asano, K. \& Matsubara, S. Asymmetric catalytic cycloetherification mediated by bifunctional organocatalysts. J. Am. Chem. Soc. 133, 16711-16713 (2011).

40. Hopkins, B. A., Garlets, Z. J. \& Wolfe, J. P. Development of enantioselective palladium-catalyzed alkene carboalkoxylation reactions for the synthesis of tetrahydrofurans. Angew. Chem. Int. Ed. 54, 13390-13392 (2015).

41. Zheng, $\mathrm{K}$. et al. Completely $\mathrm{OH}$-selective $\mathrm{FeCl}_{3}$-catalyzed Prins cyclization: highly stereoselective synthesis of 4-OH-tetrahydropyrans. J. Am. Chem. Soc. 134, 17564-17573 (2012).

42. Tsui, G. C., Liu, L. \& List, B. The organocatalytic asymmetric Prins cyclization. Angew. Chem. Int. Ed. 54, 7703-7706 (2015).

43. Parsons, A. T. \& Johnson, J. S. Catalytic enantioselective synthesis of tetrahydrofurans: a dynamic kinetic asymmetric $[3+2]$ cycloaddition of racemic cyclopropanes and aldehydes. J. Am. Chem. Soc. 131, 3122-3123 (2009).

44. Liu, L. et al. Catalytic asymmetric $[4+2]$-cycloaddition of dienes with aldehydes. J. Am. Chem. Soc. 139, 13656-13659 (2017).

45. Li, S. et al. Enantioselective hydrogenation of $\alpha$-aryloxy and $\alpha$-alkoxy $\alpha, \beta$ unsaturated carboxylic acids catalyzed by chiral spiro iridium/phosphinooxazoline complexes. J. Am. Chem. Soc. 132, 1172-1179 (2010).

46. Nakajima, K., Shibata, M. \& Nishibayashi, Y. Copper-catalyzed enantioselective propargylic etherification of propargylic esters with alcohols. J. Am. Chem. Soc. 137, 2472-2475 (2015).

47. Li, Z., Yu, R. \& Li, H. Iron-catalyzed C-C bond formation by direct functionalization of $\mathrm{C}-\mathrm{H}$ bonds adjacent to heteroatoms. Angew. Chem. Int. Ed. 47, 7497-7500 (2008).

48. Reisman, S. E., Doyle, A. G. \& Jacobsen, E. N. Enantioselective thioureacatalyzed additions to oxocarbenium ions. J. Am. Chem. Soc. 130, 7198-7199 (2008).

49. Moquist, P. N., Kodama, T. \& Schaus, S. E. Enantioselective addition of boronates to chromene acetals catalyzed by a chiral Brønsted acid/Lewis acid system. Angew. Chem. Int. Ed. 49, 7096-7100 (2010).

50. Maity, P., Srinivas, H. D. \& Watson, M. P. Copper-catalyzed enantioselective additions to oxocarbenium ions: alkynylation of isochroman acetals. J. Am. Chem. Soc. 133, 17142-17145 (2011).

51. Umebayashi, N., Hamashima, Y., Hashizume, D. \& Sodeoka, M. Catalytic enantioselective aldol-type reaction of $\beta$-ketosters with acetals. Angew. Chem. Int. Ed. 47, 4196-4199 (2008). 
52. Evans, D. A. \& Thomson, R. J. Ni(II) tol-BINAP-catalyzed enantioselective orthoester alkylations of $\mathrm{N}$-acylthiazolidinethiones. J. Am. Chem. Soc. 127, 10506-10507 (2005).

53. Rueping, M., Volla, C. M. R. \& Atodiresei, I. Catalytic asymmetric addition of aldehydes to oxocarbenium ions: a dual catalytic system for the synthesis of chromenes. Org. Lett. 14, 4642-4645 (2012).

54. Braun, M. \& Kotter, W. Titanium(IV)-catalyzed dynamic kinetic asymmetric transformation of alcohols, silyl ethers, and acetals under carbon allylation. Angew. Chem. Int. Ed. 43, 514-517 (2004).

55. Lee, S., Kaib, P. S. J. \& List, B. Asymmetric catalysis via cyclic, aliphatic oxocarbenium ions. J. Am. Chem. Soc. 139, 2156-2159 (2017).

56. Wang, L. et al. The important role of the byproduct triphenylphosphine oxide in the magnesium(II)-catalyzed enantioselective reaction of hemiacetals and phosphorus ylides. Angew. Chem. Int. Ed. 57, 9088-9092 (2018).

57. Jnoff, E. \& Ghosez, L. Asymmetric Diels-Alder reactions of 2-azadienes catalyzed by a chiral copper(II) complex. A general route to enantiomerically pure piperidones. J. Am. Chem. Soc. 121, 2617-2618 (1999).

58. Willis, M. C., Cutting, G. A., Piccio, V. J.-D., Durbin, M. J. \& John, M. P. The direct catalytic enantioselective synthesis of protected aryl $\beta$-hydroxy- $\alpha$ Amino acids. Angew. Chem. Int. Ed. 44, 1543-1545 (2005).

59. Evans, D. A., Miller, S. J., Lectka, T. \& von Matt, P. Chiral bis(oxazoline) copper (II) complexes as Lewis acid catalysts for the enantioselective DielsAlder reaction. J. Am. Chem. Soc. 121, 7559-7573 (1999).

60. Evans, D. A., Downey, C. W. \& Hubbs, J. L. Ni(II) bis(oxazoline)-catalyzed enantioselective syn aldol reactions of $N$-propionylthiazolidinethiones in the presence of silyl triflates. J. Am. Chem. Soc. 125, 8706-8707 (2003).

61. Poisson, T., Yamashita, Y. \& Kobayashi, S. Catalytic asymmetric protonation of chiral calcium enolates via 1, 4-addition of malonates. J. Am. Chem. Soc. 132, 7890-7892 (2010).

62. Chen, $\mathrm{L}$. et al. $\mathrm{Bu}_{4} \mathrm{NI}$-catalyzed $\mathrm{C}-\mathrm{O}$ bond formation by using a crossdehydrogenative coupling (CDC) reaction. Chem. Eur. J. 17, 4085-4089 (2011).

63. Meltzer, P. C., Wang, P., Blundell, P. \& Madras, B. K. Synthesis and evaluation of dopamine and serotonin transporter inhibition by oxacyclic and carbacyclic analogues of methylphenidate. J. Med. Chem. 46, 1538-1545 (2003).

64. Evans, D. A., Downey, C. W., Shaw, J. T. \& Tedrow, J. S. Magnesium halidecatalyzed anti-Aldol reactions of chiral $\mathrm{N}$-acylthiazolidinethiones. Org. Lett. 4, 1127-1130 (2002).

65. Fujioka, H. et al. Reaction of the acetals with TESOTf-base combination; speculation of the intermediates and efficient mixed acetal formation. J. Am. Chem. Soc. 128, 5930-5938 (2006).

66. Zhao, W., Li, Z. \& Sun, J. A new strategy for efficient synthesis of medium and large ring lactones without high dilution or slow addition. J. Am. Chem. Soc. 135, 4680-4683 (2013).

\section{Acknowledgements}

We greatly appreciate the financial support from the National Natural Science Foundation of China $(21722204,21472112$, and 21432003).

\section{Author contributions}

G.W. developed the catalytic enantioselective reaction and expanded the scope. X.X. and Z.W. prepared the carboxylic acid derivatives and characterized racemic products. G.L. performed the computational experiments on the stereocontrol modeling. Y.M. discussed the results and commented on the manuscript. L.L. conceived and supervised the project, and wrote the manuscript.

\section{Additional information}

Supplementary Information accompanies this paper at https://doi.org/10.1038/s41467019-08473-x.

Competing interests: The authors declare no competing interests.

Reprints and permission information is available online at http://npg.nature.com/ reprintsandpermissions/

Journal peer review information Nature Communications thanks Lei Gong, Doron Pappo, and the other anonymous reviewer for their contribution to the peer review of this work.

Publisher's note: Springer Nature remains neutral with regard to jurisdictional claims in published maps and institutional affiliations.

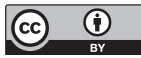

Open Access This article is licensed under a Creative Commons Attribution 4.0 International License, which permits use, sharing, adaptation, distribution and reproduction in any medium or format, as long as you give appropriate credit to the original author(s) and the source, provide a link to the Creative Commons license, and indicate if changes were made. The images or other third party material in this article are included in the article's Creative Commons license, unless indicated otherwise in a credit line to the material. If material is not included in the article's Creative Commons license and your intended use is not permitted by statutory regulation or exceeds the permitted use, you will need to obtain permission directly from the copyright holder. To view a copy of this license, visit http://creativecommons.org/ licenses/by/4.0/.

(C) The Author(s) 2019 